\title{
Die ontwikkeling vanaf 'n horti-kulturele na 'n simplistiese agrariese ekonomie in die leefwêreld van die Bybel ${ }^{1}$
}

\author{
G J Volschenk \\ Navorsingsassosiaat: Departement Nuwe-Testamentiese Wetenskap \\ Universiteit van Pretoria
}

\begin{abstract}
Development of Biblical society from a horti-cultural economy to a simplistic agrarian economy

The aim of this article is to study the evolution of the ancient economy from a horti-cultural one to a simplistic agrarian economy. The evolution is imbedded in the socio-historical, political and economic context of the ancient era. The historical overview came to the conclusion that the antecedents of the Biblical jubilee were present in the ancient society. These are namely the conflict between landtenancy and landlessness, the kinship institution being under pressure, greater social stratification through exploitation by the elite and the escalation of conflict between city and country.
\end{abstract}

\section{INLEIDING}

Die onderhawige artikel ondersoek die ontwikkeling van die antieke ekonomie vanaf 'n horti-kulturele na 'n simplistiese agrariese ekonomie. In 'n volgende artikel word aandag gegee aan die ontwikkeling vanaf 'n simplistiese na 'n gevorderde agrariese ekonomie in die leefwêreld van die Bybel (Volschenk [2002]). Hierdie twee fases van ontwikkeling is ingebed in die breë sosio-historiese en polities-ekonomiese agtergrond van die antieke era.

\footnotetext{
${ }^{1}$ Dr Gert J Volschenk (MDiv, DD) is as navorsingsassosiaat betrokke by prof dr Andries G van Aarde se navorsingsprojek "Bybelse Teologie en Hermeneutiek", Departement Nuwe-Testamentiese Wetenskap, Fakulteit Teologie, Universiteit van Pretoria.
} 
Die historiese oorsig toon 'n onderskeid tussen die Grieks-Romeinse en NabyeOosterse ekonomie. Die pre-geskiedenis is 'n holistiese eenheid. Die samelewing het ontwikkel vanaf 'n horti-kulturele na 'n simplisties agrariese samelewing. Die ontwikkeling van die ploeg was die belangrikste innovasie wat verrykende sosiale en kulturele verandering veroorsaak het. Egipte is 'n voorbeeld van die simplistiese agrariese samelewing. In Egipte was godsdiens en ekonomiese surplus ineengevleg. In die tyd het professionele weermagte en politieke burokrasieë ontstaan. Geld het nog nie in die simplistiese agrariese samelewing bestaan nie. Ruilhandel was aan die orde van die dag. Die simplisties agrariese samelewing is al meer gekenmerk deur sosiale stratifikasie en ongelykheid.

Die Hellenisme was 'n mengkultuur wat alle lewensterreine beïnvloed het. Die Hellenisme het invloed uitgeoefen op die terrein van oorlogstegnieke, administrasie, belasting en intensifisering van die ekonomie. Hellenisme het die sosiale stratifikasie geïntensifiseer en groter skeiding gebring tussen die aristokrasie en die kleinboere en landvolk. Die heerskappy van die Ptolemeërs is gekenmerk deur stryd en konflik. Die heersers het deur middel van belastings en grondbesit die kleinboere of landvolk verarm en geëksploiteer deur middel van skuld. Die historiese oorsig kom tot die gevolgtrekking dat die basiese kernfaktore wat 'n rol gespeel het in die Bybelse jubilee, ook hier figureer, naamlik:

- Die stryd om grondbesit en grondloosheid;

- Groter sosiale stratifikasie as gevolg van eksploitasie deur die elite;

- Die familiale instelling verkeer onder geweldige druk; en

- Toenemend-e konflik tussen stad en platteland.

\section{2. 'N HISTORIESE OORSIG}

Die eerste-eeuse Mediterreense ekonomie word binne die breë raamwerk van die antieke wêreld beskou. Die uitsluiting van die Nabye Ooste in die antieke tydvak is nie arbitrêr nie, en die toepassing van die etiket antieke kan slegs gerieflikheidshalwe en op grond van tradisie toegepas word. Finley (1985:28) wys op die radikale verskil tussen die Nabye-Oosterse ekonomie en die Grieks-Romeinse ekonomie. Die ekonomiese patroon 
van die Grieks-Romeinse wêreld was essensieel en pertinent gegrond op privaateienaarskap, of dit nou net 'n paar akkers was of die enorme gebiede van die Romeinse senators en keisers. Dit was 'n wêreld van privaathandel en privaat-vervaardiging. Die Nabye-Oosterse ekonomie daarteenoor:

... were dominated by large palace-or-temple-complexes, who owned the greater part of the arable, virtualy monopolized anything that can be called "industrial production" as well as foreign trade (which includes inter-city trade, not merely trade with foreign parts), and organized the economic, military, political and religious life of the society through a single complicated, bureaucratic, recordkeeping operation for which the word "rationing", taken very broadly, is as good a one-word description as I can think of.

(Finley 1985:28)

Die historiese en argeologiese data in verband met die agrariese situasie in die eerste eeu is baie min. Die historiese raamwerk waarbinne die ekonomiese situasie van Jesus en die eerste-eeu ondersoek word, word tereg deur Hengel (1973:6) genoem, Palestine as a bone of contention between Ptolemies and Seleucids. Bogenoemde historiese raamwerk het 'n lang aanloop (360 jaar) en is 'n ineengevlegde eenheid. Die geskiedenis van die Nuwe-Testamentiese tye het ' $n$ lang aanloop en kan nie bloot skematies voorgestel word nie. Hengel (1973:1) wys Nuwe Testamentici op bogenoemde ineengevlegdheid en dui aan dat teen die tyd van Jesus was Palestina alreeds onder Hellenistiese regering en die gevolglike kulturele invloed vir die afgelope 360 jaar. Hengel (1973:1; Stegemann \& Stegemann 1999:1) maan Nuwe Testamentici om die differensiasie ernstig te neem en nie net skematies voor te stel nie. Die gevolge van bogenoemde geskiedenis moet inaggeneem word. Die pre-history of Christianity word verkeerdelik beskryf as die history of New Testament times.

Die volgende breë prentjie kan van die antieke ekonomie gevorm word (Hengel 1973; Finley 1985; Oakman 1986; Fiensy 1991). Die gebruik van verskillende opskrifte 
vir die verskillende tydvakke hef nie die holistiese beeld van bogenoemde pregeskiedenis op nie, maar word gebruik vir sistematiese uiteensetting.

\section{DIE LENSKI-MODEL VAN 'N SIMPLISTIES-AGRARIESE LEEFWÊRELD}

\subsection{Tegnologie}

Lenski \& Lenski (1991) maak in hulle boek onderskeid tussen simplisties-agrariese gemeenskappe, waarvan Egipte ${ }^{2}$ 'n voorbeeld is en 'n gevorderde agrariese gemeenskap, waarvan die Romeinse Ryk 'n voorbeeld is. Die grootste innovasies in mensegeskiedenis het in die vierde/derde eeu vC plaasgevind. Lenski (1991:175) beskryf die innovasies soos volg: "The innovations of that period included the invention of the plow, the harnessing of animals to pull wagons and plows and their use as pack animals, the harnassing of wind power for sailboats, the invention of writing and numerical notation, and the invention of the calender." Van hierdie innovasies het die ploeg die grootste potensiaal vir sosiale en kulturele veranderings gehad. Boere het twee universele probleme ondervind, naamlik onkruidbeheer en om die vrugbaarheid van die grond te behou. Die ploeg het die bewerking van verskillende soorte grond moontlik gemaak. Groter stukke grond kon ook bewerk word - dus 'n evolusie vanaf die bewerking van 'n tuin (hortikultureel) na die bewerking van 'n land (landbou/agri-cultura). Met die koms van die ploeg is diere, veral osse, ingespan om dit te trek. Dit het gelei tot onkenbare vooruitgang. Die ploeg het gelei tot groter produktiwiteit - groter stukke grond is bewerk. Verder het dit gelei tot "larger economic surplus and new and more complex forms of social organization" (Lenski 1991:176).

2 Die geskiedenis van Egipte kan in die volgende tydsfases ingedeel word:

- Prehistoriese en ou koninkryk (tot by $2200 \mathrm{vC}$ );

- Eerste intermediêre periode, middel koninkryk, tweede intermediêre periode (2200-1570);

- Vroëe nuwe koninkryk (157-1375 vC);

- Amarna periode (137-1300 vC);

- Laat nuwe koninkryk (1300-1100 vC);

- $\quad$ Post imperiale periode (1100-700 vC);

- $\quad$ Etiopiese periode en Saïtiese periode (700-525 vC);

- Persiese, Ptolemese en Romeinse periode (525 vC-70 nC) (kyk Wilson 1982:39).

Die onderhawige ondersoek fokus op die laaste periode, naamlik $525 \mathrm{vC}-70 \mathrm{nC}$. 
Die tegnologiese veranderings het geakkumuleer tot verdere ontwikkelings. Lenski (1991:177) meld die volgende ontwikkelings as tekens van die aanbreek van die beskawing. Die eenvoudige tekens wat vanaf $8000 \mathrm{vC}$ gebruik is om hoeveelhede en tipe kommoditeite wat geproduseer en verhandel is, te beskryf, het ontwikkel in sisteme van rekenkunde en skryfkunde. Verder het gemeenskappe gegroei in grote, kompleksiteit en hulle het erkenbare stede geword. Laastens het die Ryk gegroei tot 'n uitgebreide eenheid wat in Egipte gelei het tot vereniging van die hele land onder een regeerder vir die eerste keer in die geskiedenis.

\subsection{Godsdiens en die groei van ekonomiese surplus}

In die vroegste agrariese gemeenskappe het elke plek en uitgebreide huishouding 'n eie god gehad. Die bou van tempels het 'n baie duur onderneming geword en het gegroei tot groot besigheidsgeleenthede. Bogenoemde ontwikkeling het gelei tot die ontstaan van die skryfkuns. Lenski (1991:178) beskryf die "Mesopotamian city-states as theocrasies, since the local deity was regarded as the real ruler and the king merely as his 'tenant farmer'”. In Egipte het die heerser self die fisiese verskyning van 'n god geword. Hy was die besitter van die land en was geregtig op 'n deel van die opbrengs. Na aanleiding van sekularisasie, veral in Mesopotamië, het institusionalisering in die gemeenskappe plaasgevind. 'n Nuwe instelling, naamlik die politiek het ontstaan. Dit het verseker dat die ekonomiese surplus van die kleinboere oorgedra word na die regerende klas.

Binne Mesopotamië ${ }^{3}$ en Egipte het godsdiens 'n belangrike legitimerende rol gespeel in die produksie en oordragproses van 'n ekonomiese surplus. Die kleinboere is deur 'n sekulêre en politieke ideologie, dit wil sê 'n sisteem van oortuigings ten opsigte van die bonatuurlike, gemotiveer om hulle surplus aan ander af te staan (vgl Lenski 1991:178). Godsdiens verskaf die rasionaal om die politieke sisteem en die harde

\footnotetext{
3 Mesopotamië beteken letterlik die land tussen twee riviere, die Tigris en die Eufraat (Gorden 1982:359). Van Zyl (1977:48) beskryf die opkoms van Mesopotamië soos volg:

Reeds sedert die laat vierde millennium het 'n beskawing in Mesopotamië gegroei, min of meer gelyktydig met die in Egipte. Die Sumeriërs, 'n nie-Semities-sprekende volk aan die benedelopende van die Tigris en Eufraat, het stadigaan ontwikkel. Die uitvinding van die wiel, drooglegging van landerye, stedebou, skrifkunde, kultuur en godsdiens, die organisasie van arbeid, die ekonomie en plaaslike regering het in die eerste helfte van die tweede millennium met rasse skrede vooruitgegaan. Die land was nie verenig nie, maar het bestaan uit 'n aantal stadstaatjies met 'n teokratiese regering wat nou verweef was met die landbou.
} 
ekonomiese gevolge te regverdig (Lenski 1991:178). Die twee veroweringstate, Egipte en Mesopotamië (letterlik tussen twee riviere), het rivierkulture en kultusse gehad, wat sterk landbou, militêre mag en burokrasie (regering op dorpievlak) tot gevolg gehad het. Egipte is die gawe van die Nyl. Egipte is primêr woestynland en die vloei van die $\mathrm{Nyl}$ alleen het die menslike lewe moontlik gemaak. Die Nyl het Egipte gekontrasteer met die buurlande en die Egiptenare het dit beskou as die besorgdheid van die gode vir die land (Wilson 1982:39). Egipte se welvaart en mag is gegrond op 'n stewige landbou (Wilson 1982:41). Vis, ganse en eende was volop en deel van die Egiptenare se dieet. Die rivier was verder 'n belangrike bron van vervoer. Die Egiptenare was ook ervare seevaarders.

Egipte se godsdiens was sinkretisties ('n vermenging van gode) van aard. Drie tipes gode word onderskei, naamlik gode van plek, kosmiese gode en gode wat net vir sekere funksies van die lewe verantwoordelik was (vgl Wilson 1982:56-58). Die god Atum beteken die Alles en sy plek was op 'n stukkie grond wat uit die waters van chaos gekom het en die elemente van die kosmos geskep het. Net so het 'n nuwe lewe gekom uit die vloedwaters van die Nyl. Atum se twee kinders was Shu (god van die lug) en Tefnut (god van vogtigheid) (Wilson 1982:58).

\subsection{Bevolkingsgroei}

Egipte was die grootste en polities die stabielste van die simplistiese agrariese gemeenskappe van die antieke tyd. Egipte was 'n verenigde en onafhanklike nasie in die tyd. Dit was die gevolg van hulle natuurlike geografiese ligging (afgegrens deur die woestyn, berge en die see). In die tweede helfte van die tweede millennium het Egipte 'n uitbreidingsprogram begin en het hulle grense uitgebrei na Sirië en Soedan. Egipte het 'n bevrydingsdrang gehad en ter wille van hulle beskerming het hulle die ryk so groot as moontlik probeer uitbrei. Egipte het 'n groot wêreldmag geword wat nou en dan sy invloed laat geld het in die wêreldsake (Van Zyl et al 1977:54).

\subsection{Die politiek en die groei van die staat}

Uitbreidings en verowerings het organisatoriese probleme veroorsaak vir die heersers van die vroeë agrariese gemeenskappe. Tradisionele vorme van regering, wat gegrond was op familiale bande, was nie meer voldoende om die gemeenskapsake te reël nie. Die 
bevolkings het te groot geword. Ander regeringsstrukture moes geskep word in die plek van familiebande. Die nuwe patrone is duidelik sigbaar in die ontwikkeling van militêre en sosiale bande.

Die verskuiwing van gewone skermutselings tussen konings ${ }^{4}$ na die uitbouing van koninkryke, het gelei tot die ontstaan van professionele weermagte. Egipte het byvoorbeeld net staat gemaak op vreemde huursoldate. Die soldate was 'n koninklike weermag. Die weermag is deur die koning betaal en versorg. Hulle het beskerming gebied teen interne opstande en eksterne bedreigings (kyk Van Zyl et al 1977:54).

Die ontstaan van 'n professionele weermag het verder die mag van die regerende klas versterk. Groot militêre veroweringstate, soos die Perse, Grieke en Romeine kom tot stand. Met groter mag kan die regerende klas makliker die ekonomiese surplus van die kleinboere bekom, sodat laasgenoemde se bestaansmiddele verminder het. Die elite kon as gevolg van die verhoogde produktiwiteit, meer ekonomiese surplus van die kleinboere verkry deur middel van belasting, geskenke, tiendes en rente. Die inkomstebronne was nodig vir die instandhouding van die elite se ambagsmanne, diensknegte en soldate. Die vooruitgang in sosiale organisasie het groter verdeeldheid in arbeid en klasse gebring, dit wil sê groter sosiale ongelykheid. Bogenoemde verandering het aanleiding gegee tot die gevorderde agrariese gemeenskap (Lenski 1991:187-188).

Administrasieprobleme het vermenigvuldig met die uitbreidings van die regering. Nuwe poste is geskep en sodoende ontstaan daar owerheidsburokrasieë (Lenski 1991:181). Skrifgeleerdes het belangrike mense geword en geskrewe verslae het algaande belangriker geword. In simplistiese agrariese gemeenskappe was skryfkuns 'n komplekse ambag, wat deur 'n paar individue, veral rykes en magtiges se kinders, na 'n lang opleiding (veral in Egiptiese hiërogliewe) bemeester is. Skrifgeleerdes was polities dus baie belangrik en deel van die ondersteunende klas (retainers) wat as bemiddelaars tussen die elite en die landvolk opgetree het (Lenski 1991:181; kyk ook Crossan 1998:230-235).

Die groei van die ryke en die ontwikkeling van burokrasieë, het gelei tot die vestiging en standaardisering van die regstelsel. Bloedwraak is later vervang met meer

\footnotetext{
${ }^{4}$ Goodenough (1928:55-102) gee 'n oorsig van die politieke filosofie rakende koningskap in die Hellenisme.
} 
gematigde arbitrasie van geskille. Reg en geregtigheid is deur bekwame en magtige mense van die gemeenskap toegepas.

\subsection{Die ekonomie: Die eerste monetêre stelsels en handelsgroei}

Van Zyl (1977:54) beskryf die ontwikkeling van die feodale stelsel en grondbesit in Egipte. Volgens die feodale stelsel het die grond aan die farao behoort. 'n Nuwe sosiale orde het ontstaan wat later deur Egipte voortgesit is in Palestina. Die farao het die grond aan die heersersklas verhuur wat dit weer onderverhuur het aan die ondergeskikte bevolking. "Hierdie ondergeskiktes moes die belastings betaal en verpligte diens, in besonder krygsdiens, verrig. In Siro-Palestina is daar selfs Hyksos-prinse as vasalheersers aangestel" (Van Zyl et al 1977:54).

Geld was afwesig in die simplistiese agrariese gemeenskap ${ }^{5}$. Die gestandardiseerde ruilmiddels het byvoorbeeld bestaan uit graan. Lone, rente, belasting en ander verpligtinge is met spesifieke hoeveelhede graan betaal. Die vervaardiging van munte het eers in 'n laat stadium van die simplistiese agrariese gemeenskap begin. Die groei van monetêre sisteme het geweldige invloed gehad op die sosiale ontwikkeling. Geld het die beweging, verhandeling en die produksie van goedere en dienste gefasiliteer. Die ontstaan van 'n monetêre stelsel of sisteem het verder die ontstaan van makte tot gevolg gehad. Die individu het produkte vervaardig om te verkoop aan mense wat niks in ruil kon of wou gee nie. Dus is die aanvraag van goedere en dienste verhoog (kyk Lenski 1991:184).

Die gevolge van 'n monetêre stelsel is die opkoms van handelaars - die middelman. Hulle koop en verkoop deur in die aanvraag van ander mense te voorsien. Verder het hulle ook 'n nuwe aanvraag of 'n mark geskep. Handelaars het nuwe begeertes en behoeftes geskep en sodoende ekonomiese aktiwiteit gestimuleer. 'n Direkte gevolg van die geldekonomie is die ondermyning van die familiale of uitgebreide

\footnotetext{
5 Van Aarde (1994:579) beskryf die oorgang vanaf die horti-kulturele samelewing (7000-3000 vC) na die simplistiese agrariese samelewing (3000 vC-1800 nC) soos volg:

... emergence of world religions, the process of urbanization, the growth of conquest states, the increase of inequality in social stratification and the increase of the scarcity of resources. Simultaneously, writing and money were invented as media .... for the control of the scarce resources through power and the inequal distribution of authority. Scarce resources can be material goods: food, housing, land and income, as well as non-material resources: values, status, domination over territory, honor and prestige...
} 
familiale sisteme. Lenski (1991:184) beskryf die verdere invloed van die geldekonomie soos volg:

In the long run, a money economy subverts many of the values of simpler societies, especially the cooperative tendencies of extended kin systems. It fosters instead a more individualistic, rationalistic, and competitive approach to life, and lays a foundation for many of the attitudes and values that characterize modern industrial societies.

Die geldekonomie was baie beperk in voorkoms, veral in die simplistiese agrariese gemeenskap van die antieke Midde Ooste. Die landelike gemeenskappe is nie veel beïnvloed deur die geldekonomie nie.

\subsection{Stratifikasie en toenemende ongelykheid}

Die nuwe opkomende en uitgebreide sosiale en kulturele verskille het interne skeiding en selfs konflik binne 'n simplistiese agrariese gemeenskap veroorsaak. Drie ernstige skeidings het in die gemeenskappe ontstaan, naamlik die skeiding tussen die klein regerende klas en die groter massa landvolk wat geen inspraak in die politieke besluitneming gehad het nie en wat al hulle surplus produksie aan die regerende klas moes oorhandig. Tweedens was die skeiding tussen die stedelike minderheid teenoor die meerderheid plattelanders. Die derde skeiding was tussen die minderheid geletterdes en die meerderheid ongeletterdes (Lenski 1991:185).

Verskillende groepe het onderskeidelik hulle eie subkulture. Die klein en geletterde stedelike regerende klas het in 'n ander wêreld geleef as die ongeletterde, plattelandse, meerderheid kleinboere. Die onderskeid het binne dieselfde gemeenskap plaasgevind. Die subkultuur van die regerende klas sluit meer beskaafde sake in soos filosofie, kuns, letterkunde, geskiedenis, en wetenskap. Hulle het 'n minagting gehad vir fisiese arbeid.

\subsection{Verlaging in tegnologiese innovasie}

Lenski (1991:175) het die hoofstuk oor agrariese gemeenskappe begin met die tegnologiese innovasie, maar ironies sluit hy die spesifieke afdeling in verband met die 
simplistiese agrariese gemeenskap af met 'n paragraaf oor die verlaging in tegnologiese innovasie. Ten spyte van groter populasies en meer inligting wat beskikbaar was, was daar nie groter innovasies in die laat simplistiese agrariese gemeenskappe nie. Lenski (1991:186) skryf die vertraging in tegnologiese innovasie toe aan wat hy noem feedback. Terugvoer is die gevolg van 'n krag wat omkeer en terugkom en die oorspronklike krag beïnvloed. Positiewe terugvoer is waar die sekondêre gevolge die oorspronklike krag versterk en bevorder. Negatiewe terugvoer is waar die sekondêre krag van tegnologiese vooruitgang in sosio-kulturele evolusie die oorspronklike krag verswak of vernietig.

\section{HELLENISME}

\subsection{Inleiding}

Aleksander die Grote ${ }^{6}$ (356-323 vC) slaan 'n nuwe weg in na 'n eenheidsryk met 'n omvattende eenheid van taal, gebruike en beskawing. Van Zyl (1977:220, 221; Turner 1982:77-79) toon aan dat die helleniseringsproses 'n subtiele beïnvloeding was onder die heerskappy van Aleksander die Grote. Aleksander se strategie was soos volg:

- Stig verskeie hellenistiese "kolonies", onder andere Aleksandrië, Sebaste, Philadelphia en Ptolemais.

- Aanmoediging van huwelike tussen die soldate en die inwoners van die verowerde volke of gebiede.

- Helleniseer die wêreld met die oortuigingskrag van die idees en subtiele beïnvloeding.

Hellenisme is 'n kultuur wat saamgestel is uit Griekse en Oosterse elemente. Hellenisme is die voortsetting van die Griekse kultuur onder nuwe omstandighede. Louw (1983:2) beskryf Hellenisme as: "'n gerieflike benaming vir die drie eeue tussen Aleksander die Grote en die koms van Christus, ten tye waarvan die Griekse kultuur tot wêreldbeskawing

\footnotetext{
${ }^{6}$ Aleksander die Grote is gebore in $356 \mathrm{vC}$ en sterf in $323 \mathrm{vC}$ op 33 jarige ouderdom aan koors te Babilon. Hy verslaan die Persiese heersers, Granicus (334) en Issus (333). Hy verslaan Egipte in 330 vC. Sy ryk sluit nou in Klein-Asië, Sirië, Palestina en Egipte. Josefus (Antiquities IX. viii. 3-6) beskryf Aleksander die Grote se verowering van Tirus in $330 \mathrm{vC}$. Laasgenoemde word bevestig deur die Talmud (Yoma 69a). Die apokriewe boek van 1 Makkabeërs (1:1-8; 6:2) verwys na Aleksander die Grote (kyk Turner 1982:77).
} 
ontwikkel het sover dit nagevolg, voortgesit en vervorm is in verbinding met ander beskawings van die nabye Ooste'. Hellenisme is inderdaad ' $n$ vermenging, maar ook 'n verspreiding. Dit is 'n nuwe kultuur, 'n mengkultuur, wat oor die grootste deel van die destydse wêreld versprei het. Hieruit het die idee van 'n oikoumene - 'n bewoonde wêreld ontstaan waarin 'n nuwe vorm van Grieks, naamlik koine ontstaan het. Die destydse wêreld het een groot wêreldgemeenskap geword met Grieks as voertaal. Die grense van die Hellenisme is nie skerp afgegrens nie. Hellenisme spreek nie 'n land of 'n volk aan nie, maar die wêreld. Die Griekse taal word gepraat, selfs lank nadat Griekeland opgehou het om te bestaan. Die wêreld praat nou Grieks.

Hellenisme het die einde van twee-groot-strome-kultuur beteken - die Oosterse en die Griekse, maar die begin van die nuwe wêreld stel in baie opsigte die begin van die moderne wêreld. Dit was die skakel tussen Griekeland en Rome, die bodem waarin die Christendom ${ }^{7}$ gespruit het.

Die Hellenistiese beskawing was 'n mag gewees wat alle lewensterreine omsluit het. Dit was 'n mag waarvan die gevolge militêr, seviel en sosio-ekonomies sigbaar was.

7 Pilch (1997:119-125) vestig die andag op Nuwe-Testamentici se anakronistiese gebruik van terme soos "Jood", "Griek" en "Christendom" in die Bybel. Die probleem met die gebruik van die terme lê by vertalers en hermeneute van die Westerse kultuur met 'n gebrek aan historiese bewussyn en etnosentriese tendense. Pilch $(1997: 121,122)$ stel 'n drie deling van die geskiedenis van Israel voor, wat dien as verwysingsraamwerk vir die gebruik van die terme.

- $\quad$ Die eerste tempel periode $(950 \mathrm{vC}-586 \mathrm{vC})$ is die periode van die eerste tempel godsdiens (Salomo se tempel). Die volk word in die tyd beskryf as Israeliete (seuns of volk van Israel in die Hebreeuse Bybel).

- $\quad$ Die tweede tempel periode (520 vC-70 nC) beskryf die godsdiens van die tweede tempel (herbou deur Esra en Nehemia). Die land word Judea genoem en die inwoners Judeërs. Die derde periode is die tyd van die Rabbynse Judaïsme (vanaf $90 \mathrm{nC}$ - tot en met vandag). Die godsdiens van die periode is die normatiewe Judaïsme.

Pilch (1997:122) beskryf die gebruik van die term binne laasgenoemde konteks soos volg:

The religion of this period is currently termed "normative Judaism" deriving from Pharisaic scribalism which is the foundation of contemporary Jewish belief and practice. It is this form of Judaism and these Jews that are familiar to the contemporary world. In the modern day, the terms Jewish religion, Jewish beliefs, et cetera, are most appropriate but cannot and should not be retrojected into the Bible. Such anachronism, however, is unfortunately too common in many religious education programs. 
Die volheid van die mag was uitdrukking van die mag van die Griekse gees (spirit) wat alle vlakke van die lewe beïnvloed het (Hengel 1973:57).

Die gevolge is ook sigbaar in die literatuur, filosofie en godsdiens. Die enigste toegang en brug na hierdie terreine is die taal van die Hellenisme, naamlik die koine Grieks. Die Jode (Judeërs - GV) het die Hellenistiese beskawing as sekulêre mag teëgekom in die vroeëre uitbreidings van Aleksander en die ryke van die Diadochi wat daarop gevolg het. Die hele Ooste het hierdie mag ervaar. Verskeie kenmerke van die Hellenisme het 'n invloed uitgeoefen op Palestina.

\subsection{Oorlogstegnieke}

Die Joodse (Israelitiese - GV) soldate wat deur die Ptolemeërs gebruik is, het baie geleer by hierdie oorlogstegnieke. Die heilige oorlog in die Joodse apokaliptiek is sterk deur bogenoemde tegnieke beïnvloed, asook die latere Makkabese ${ }^{8}$ opstand en die Joodse uitbreidingsbeleid wat later gevolg het (vgl Hengel 1973:54; Van Zyl 1977:54, 219-222). Fillipus II (359-336 vC) het Griekeland ingeval en 'n einde gemaak aan die Griekse stadstate. Aleksander het Fillipus in $336 \mathrm{vC}$ opgevolg en was intelligent, vol waagmoed en 'n vaardige militaris. Groot dele van Klein-Asië, Foenisië, Palestina, Egipte en Babilonië is verower. Die weermag van Aleksander was sover as in Indië (Turner 1982:77-78; Edwards 1992:313).

\subsection{Streng administrasie en belastingsisteem}

Die Ptolemeërs se streng administrasie en belastingsisteem, veral die Griekse instelling om agterstallige gelde in te vorder, het ' $\mathrm{n}$ groot invloed uitgeoefen. Dit het ' $\mathrm{n}$ vaste instelling geword in Judea in die eeue wat gevolg het. Die mag van die staat het uitgemond in die landvolk se haat jeens die tollenaars. Die ontwikkeling van die grondwet van die Joodse tempelstaat van die Nuwe-Testamentiese tyd, met 'n fyn balans tussen die hoëpriester en die Sanhedrin, dateer waarskynlik ook terug na die tyd van die Ptolemeërs (Hengel 1973:55).

\footnotetext{
8 Josefus (37/38-100 nC) was die bevelvoerder van die Galilese leer en historikus. Hy beskryf die eersteeeuse Judea onder die Romeinse heerskappy. Die oorlog tussen die Jode en Romeine in 66-70 nC word ook deur Josefus beskryf. Sy eerste werk Bellum Judaicum handel oor die oorlog met die Romeine. Twintig jaar later verskyn sy Antiquitates Judaicae in 20 volumes (Goldin 1982987-988; McLaren 1998).
} 
Volgens Louw $(1983: 38,40)$ is belasting op feitlik alles gehef. Van die bekendste belasting was: grondbelasting; heffing op die myne, dit wil sê op die minerale; tolgeld by die hawens of tolhekke; heffings op die land en by die markte; heffing op privaatbesit van vee; en ander diverse belastings soos hoofdebelasting en handelsbelasting. Uit die Masedoniese ryk is vroeg al belasting wat eisphora genoem is, op 'n persoon se totale besit gehef. Die eienaar het self 'n verklaring hieroor gemaak. Dit was populêre bronne van inkomste vir die Hellenistiese vorste. Die belasting is gebaseer op ' $n$ inskrywing, dit wil sê registrasie of sensus (vgl Edwards 1992:314).

\subsection{Ekonomiese aktiwiteite}

Die Grieke het 'n vermoë vir organisasie, logiese en tegniese sisteme ontwikkel in Palestina, in diens van die Ptolemese staat en vir hulleself, om nog meer wins uit die rykdom van die land te maak. Hulle het die plaaslike en uitvoerhandel in Palestina verhoog in samewerking met die Foenisiërs. Handelsbande is versterk met Egipte, Arabië, Agaie en die westelike Klein-Asië. Die Joodse diaspora het ook uitgebrei deur middel van handel en deels deur slawerny. Die lang vredestyd in die derde eeu het ook gelei tot ekonomiese ontwikkeling, wat 'n klimaks bereik het in 285-246 vC. Hellenisme het op ekonomiese gebied nie 'n breuk veroorsaak nie, maar ekonomiese ontwikkeling net geïntensifiseer (Hengel 1973:56).

\subsection{Aristokrasie en Hellenisme}

In Palestina self het feitlik elke inwoner in kontak gekom met die nuwe meesters, of dit nou soldaat, amptenaar, handelaar of grondeienaar was. Die teokratiese program van skeiding van die nie-Judese omgewing is tot op die uiterste beproef. Die keuse het gelê tussen die ekonomiese en sosiale moontlikhede wat die Hellenistiese beskawing hulle gebied het of hulle moes volhard het in die tempelstaat, wat die reputasie gehad het van separatisme. Die jongmense wou uitbreek uit die engheid van die Joodse tradisie en wou die Hellenisme ten volle ondersteun (Hengel 1973:56).

Belangstelling in die Hellenisme het net gekom vanuit die opperklasse en die aristokrasie in Jerusalem. Intensiewe ekonomiese eksploitasie en sosiale onbedagsaamheid van die nuwe meesters en hulle navolgers, het die situasie van die laer strata 
van die samelewing verswak. Eersgenoemdes het net belang gestel in suiwer ekonomie. Grond was vir die opperklasse 'n verhandelbare kommoditeit, terwyl dit vir die kleinboere gegaan het om oorlewing (vgl Crossan 1998:215-222). Dit het aanleiding gegee tot die ontwikkeling van die apokaliptiek (dit beteken dat daar gehoop word dat 'n messias hulle sal red en daar 'n beter toekoms op hulle wag) en latere opstande, wat sterk sosiale elemente gehad het, tot en met die Bar Kogba opstand. Selfs die agtergrond van Jesus se gelykenisse met die klem op die groot grondeienaars, tollenaars, administrateurs, geldleners, dagloners en doeane-amptenare met die spekulasie in graan, skuldslawerny en die verhuring van grond, kan slegs verstaan word in die lig van ekonomiese toestande wat die Hellenisme in Palestina veroorsaak het.

\subsection{Die Diadochi-stryd}

Alexander die Grote dui die begin van die Hellenisme aan toe hy as koning van Masedonië by Fillipus, sy vader oorgeneem het. Die taktiek was om vinnig te werk te gaan en die hele Griekeland aan sigself te onderwerp. Toe Aleksander in $323 \mathrm{vC}$ onverwags sterf, het die ryk ook Egipte, die grootste gedeelte van Asië en Klein Asië ingesluit (kyk Turner 1982:77). Dit was 'n prestasie om die magtige Persiese ryk aan Masedonië te kon onderwerp. Na Aleksander se dood is die bestuur van die ryk aan die generaals oorgelaat. Die geskiedenis wat nou volg, staan bekend as die Diadochi-stryd, die stryd van die generaals of opvolgers.

Die ryk is in provinsies verdeel of satrapieë, waaroor 'n generaal onderskeidelik geheers het. Die bekendste was Ptolemeus van Egipte en Seleukus van Sirië en Masedonië. Nou volg 'n periode van die Diadochi-stryd, waartydens elk van die generaals die oppermag probeer bekom het, deur eindelose koalisies, sameswerings, en persoonlike ingrype (Louw 1983:12). Teen die lig van hierdie agtergrond moet die ekonomie van die eerste-eeuse Palestina beskou word. Die wedywering oor beheer van Palestina het grootliks gewoed tussen die Ptolemeërs en die Seleukiede (vgl ook Van Zyl et al 1977:50-55). 


\section{PALESTINA ONDER DIE PTOLEMEëRS}

\subsection{Politieke opkoms}

Die Ptolemese oorheersing van Palestina begin in $286 \mathrm{vC}$ toe Ptolemeus I Palestina verower het. In sy besetting van Sirië en Palestina het Ptolemeus I die ou beleid van die Farao's laat herleef. Eerstens, het die gebied 'n belangrike buffer vir Egipte gevorm teen enige aanval vanuit die noorde. Tweedens, was die hawens van Foenisië en Libanon die basis van die vlootmag van die Ptolemeërs. Derdens, was Palestina die fokuspunt vir kommersiële en karavaanroetes vanaf Mesopotamië, die Persiese Golf en Suid-Arabië. Vanuit 'n ekonomiese perspektief is dit ook 'n waardevolle verlenging vir Egipte. Laastens, wys Hengel (1973:6) dat die Ptolemeërs afhanklik was van buitelandse soldate vir hulle weermag, wat hulle veral uit Idumeërs, Arabiere en Jode verkry het (vgl Van Zyl et al 1977:222-224; Wilson 1982:39-66).

\subsection{Administrasie en belasting}

Palestina se vormende administratiewe en ekonomiese organisasie is in die GrieksRomeinse periode ontvang as gevolg van die invloed van die Ptolemeërs. Die Ptolemeërs het deur Aleksander die basiese Persiese administratiewe organisasie van Palestina geërf. Die Persiese provinsies is verdeel in kleiner provinsies, wat weer in distrikte verdeel is (Van Zyl 1977:222; Wilson 1992:60). Die Ptolemeërs het ook belangrike veranderings aangebring met hulle oorname van Palestina. Hulle beleid was om die plaaslike eenhede en lojaliteite te fragmenteer: verdeel en heers. Die provinsiale reëlings is so ingerig dat deur gebiede, stadsgebiede, militêre kolonies ensovoorts, is klein politieke eenhede geskep wat belastinginvordering vergemaklik het en jaloesie onder die amptenare teweeggebring het waarmee hulle hulle voorregte beskerm het.

Die Ptolemeërs het ook die "alomteenwoordigheid" van die koning goddelik gesanksioneer. Die konsekwensies is deurgetrek tot op grondvlak. Eerstens, was die hele land die eiendom (oikos) van die koning (Fiensy 1991:22; Hengel 1973:19; Louw 1983:33). Die grond is bewerk deur die koninklike kleinboere, onder streng toesig van koninklike amptenare. Dele van die koninklike grond is toegewys aan die militêre leiers of is as geskenke gegee aan hoë amptenare van die koning. Maar die koning kon die 
grond enige tyd terugneem. Die belangrike staatsinkomste is volgens Hengel (1973:19) verkry uit die tempelgrond onder staatsbeheer, boerdery op die koninklike grond, verskeie soorte belasting en staatsmonopolie op die belangrikste handelsware. Die invordering van belasting was streng en groot boetes is gehef op bedrog en vermyding van belasting. Die Ptolemeërs se belastingstelsel het groot invloed op die Seleukiede en Romeinse stelsels gehad. Die Joodse aristokrasie en opperklasse het bygedra met die insameling van belasting (Hengel 1973:22). Die aristokrasie het die gemoed van die volk bepaal. Die Ptolemeërs het beheer oor die aristokrasie verkry deur hulle 'n aandeel te gee in die risiko en voordele van die invordering van belasting en aksyns. Die besorgdheid in verband met die beskerming van die opbrengs van die land toon ook 'n belangstelling in die landvolk. Volgens Hengel (1973:23) het die Ptolemeërs 'n gemengde ekonomiese en politieke invloed op Palestina gehad.

Skrifgeleerdes was nie net meer aangetref in gesentraliseerde tempelstede waar hulle verantwoordelik was vir die religieus-gesanksioneerde neerskryf van instruksies van gedrag wat offers (belastings) ingesluit het nie. Skrifgeleerdes word nou ook op kleiner streekvlak aangetref, omdat dit die plek was waar die "alomteenwoordigheid" van die koning as die epifanie van 'n godheid gemanifesteer het. Die Skrifgeleerdes, as die ondersteunende klas van die elite en die middelmanne tussen die elite en landvolk, het die eis van offers (belastings) gereguleer. Die rykdom wat die Ptolemeërs met bogenoemde streng administrasie en finansiële beheer verkry het, het hulle politieke superioriteit gegee in die oostelike Mediterreense gebied gedurende die derde eeu.

Tweedens, is die titels van die Ptolemese administratiewe amptenare afgelei van die terminologie wat in groot Griekse privaatlandgoed gebruik is. Die koning regeer die staat, soos 'n gewone Griek sy huis regeer. Hengel (1973:19; ook Fiensy 1991:22) onderskei drie belangrike staatsamptenare binne die Ptolemese koningshuis. Die belangrikste persoon naas die koning is die dioiketes. Laasgenoemde was verantwoordelik vir die besittings en inkomste van die koning. Die totaliteit van die ekonomie, finansies en administrasie van die staatbestuur, insluitende belasting-invordering, is deur die dioiketes gehanteer. Die kleinste administratiewe eenheid was die dorpie (village). Die belangrike amptenare in die distrik was die militêre strategos, die oikonomos vir die 
finansiële administrasie en handel, en 'n reeks ander funksionarisse van gelyke status. Die leiersposisies is eksklusief deur die Grieke gevul.

Die verslawing van die vryburgers van Sirië en Foenisië is verbied. Die GrieksMasedoniese soldate-settelaars wou die Semitiese kleinboere as slawe gebruik om hulle grond te bewerk. Die vrylating van Joodse slawe in Egipte deur Ptolemeus II hou verband met die verbod op slawerny.

\subsection{Politieke wedywering in Jerusalem}

Die wedywering tussen die Ptolemeërs en die Seleukiede het politieke wedywering en onrus binne Jerusalem gestimuleer. Die hoëpriester was die Joodse verteenwoordiger van die regering en het geweldige beheer en invloed gehad in politieke, sosiale en finansiële aangeleenthede. Die wedywering in die binnekringe van die Joodse volk het juis plaasgevind rondom die amp van die hoëpriester. Die wedywering het veral gewoed tussen die huis van Onias en Tobias. Na die dood van Ptolemeus II Philadelfus (285-246 BCE), het die hoëpriester Onias II geweier om die belasting aan die nuwe Ptolemese regering oor te betaal, omdat hy waarskynlik hom geskaar het by die Seleukiede in die derde Siriese oorlog ( $242 \mathrm{vC})$ in die hoop op groter onafhanklikheid. Onias II se weersin in onderdanigheid het gelei tot die aanstelling van die familie van Tobias as die amptelike verteenwoordiger van die Joodse volk by die regering (Kee et al 1997:290). Magtige plaaslike prinse soos Tobias het grond en dorpe van die Ptolemeërs ontvang net om die plaaslike inwoners te kalmeer. Die Tobias-familie was tipies van die leidende Joodse families wat gewedywer het vir mag en invloed tydens die Hellenistiese en Romeinse tydperke. Tobias se seun Josef ${ }^{9}$ het Ptolemeus oorreed om laasgenoemde aan te stel as hooftollenaar, omdat Tobias meer belasting vir die regeerders kan insamel en baie troepe het om gesag af te dwing. Josef het die mag van die Tobias-familie tot 'n hoogtepunt gevoer deur ' $n$ invloedryke Ptolemese amptenaar te word. Josef is 'n tipiese voorbeeld van die plaaslike regerende klas, wat in diens geneem is om die ryk te dien met beloftes

\footnotetext{
9 Josef is, volgens Van Zyl (1977:224), uit die huis van Tobias en het persoonlik die belasting (jaarlikse tribute) aan Ptolemeus betaal om sodoende sy mag te vergroot. Hy word aangestel as belastinggaarder. Judea het egter die status as tempelland verloor en word as 'n feodale land onder die jurisdiksie van Josef. Tot met die dood van Josef in $187 \mathrm{v} C$ het die Jode as gevolg van sy optrede 'n tyd van voorspoed beleef.
} 
van voortdurende mag en welvaart. Die regeerders het aangepas by die Hellenistiese kultuur.

\subsection{Landbou en grondbesit}

Die Griekse heersers was verplig om die plaaslike erfgrond te erken, alhoewel hulle die erfbesit wou beperk. Verder was daar ook landbou-ontwikkeling in Palestina onder die Ptolemeërs. Hengel (1973:47) stel dat die ekonomiese opbloei op landbou gebied in Palestina onder die Ptolemese bewind, nie net gelei het tot 'n verhoging van staatsinkomste deur middel van belastings nie, maar ook tot bevolkingsgroei. In die bergagtige dele van Juda waar besproeing moeilik was, was die oes opbrengste laag, as ook die bevolkingsgroei. Die kleinboere is gedwing om te emigreer na nie-Joodse dele van Palestina en Egipte.

\subsection{Ekonomiese ontwikkeling en vooruitgang}

Die Foenisiese pottebakkerswerk is die aanduiding van die aanwesigheid van die Griekse kultuur in Palestina in die pre-Hellenistiese tyd. Verder dui die geld of muntstukke wat gevind is op kontak met die Griekse handelaars (Josefus Life: 30, 66-68, 128; Kyk Freyne 2000:55). Palestina het die ontmoetingspunt geword van verskeie soorte invloed vanuit die internasionale handel. Die Foenisiese invloed kan in die hele Palestina gesien word as 'n gemengde kultuur van Egiptiese, Persiese en Griekse invloede (Hengel 1973:32, $33)$.

Die Griekse taal was die lingua franca en die Griekse standaarde, gewig, geld, rekeningkunde en handel het die algemene norm geword. Die 100 jaar wat Palestina onder Ptolemese heerskappy was, was van deurslaggewende belang. Die streng administrasie en staatsbesteding was nuut en uniek in die oosterse lande (Hengel 1973:35). Egipte was 'n geldmaakmasjien en die feit dat die grond aan die koning behoort het, het daartoe bygedra. Bogenoemde konsep was vreemd aan die Grieke, maar hulle het nogtans saamgewerk met die Ptolemeërs ${ }^{10}$ in die ontwikkeling van die Ptolemese staatsekonomie en het gedeel in die winste. So het die Ptolemeërs en hulle

10 Die Ptolemëers verwys na die inwoners van Egipte wat vernoem is na die heersers in Egipte, naamlik Ptolemeus (525 vC-70 nC). Die Grieke verwys nie net na die Grieksprekende persone nie, maar ook na die ondersteuners van die Hellenistiese taal en kultuur. 
Griekse helpers Egipte in die eerste helfte van die derde eeu ontwikkel op die basis van die koningskap, sodat dit die leidende staat in die Hellenistiese wêreld geword het. Alexandrië was die brug tussen die Griekse en oosterse wêreld en het 'n belangrike rol gespeel in die ontwikkeling van die Judaïsme in Egipte en Palestina ${ }^{11}$. Die staat het die monopolie gehad in die groente, olie, linne, yster, sout, speserye en ander handelsware. Die staat het die Egiptiese ekonomie beheer en die munt-monopolie gehad. Egipte het handel gedrywe met die provinsies van die Ptolemeërs deur middel van uitvoere. Die handel het hulle, insluitend Israel, in kontak gebring met die Alexandryns-Hellenistiese kultuur. Die Griekse stede het graan van die Ptolemeërs ingevoer. Die Grieke het na Egipte toe gekom om ryk te word. Die Ptolemeërs het 'n behoefte gehad aan Griekse soldate, amptenare, beleggings en ambagsmanne, daarom was hulle immigrasie goedgesind. Die fondasies van die Ptolemeërs se politiek het in ekonomiese oorwegings gelê.

Handel was een van die belangrikste ekonomiese ontwikkelings van Palestina onder die Ptolemese regering. Die hawens van Palestina het 'n belangrike rol gespeel in die seemag van die Ptolemeërs. Palestina het graan uitgevoer na Egipte in tye wat hulle voorrade min was. Verder het Palestina olyfolie, wyn, graan en erdepotte uitgevoer. Die vind van munte wys op die handelsbloei wat Palestina beleef het. Die staat het die balsemplantasies beheer. Die wolbedryf het ook ontwikkel tot ' $n$ redelike groot industrie. In die Hellenistiese tyd was daar ook mensgemaakte damme en kanale wat landbou en besproeiing bevorder het. Tekens van visnywerheid is in die Hellenistiese tyd gevind, asook tegniese verbeterings en sekere boustyle (Hengel 1973:41-47).

\subsection{Sosiale klasverskille}

Hengel (1973:48) beskryf die sosiale omstandighede in die tyd van die Ptolemeërs baie duidelik. Die Ptolemeërs het kontak met die Semitiese opperklasse gesoek om hulle heerskappy te behou. As die Semiete die Griekse taal en Griekse manier van lewe aanneem, kon hulle gelyke regte met die Grieke verkry. Die genoemde Semitiese kringe

11 Die gebruik van die term voor $70 \mathrm{nC}$ is ook anakronisties en etnosentries. Pilch (1997:119-125; vgl afdeling 3) se opmerkings oor die gebruik van die terme "Jode" en "Grieke" geld ook vir Palestina. Vanaf $520 \mathrm{vC}$ tot $70 \mathrm{nC}$ praat ons van "Judea". Vanaf $90 \mathrm{nC}$ tot vandag praat ons van die "Joodse land" of "Joodse volk" of van "Palestina onder die Romeine". 
is die werklike proponente van die hunkering na die Hellenisering. Die gewone bevolking was net die objek van eksploitasie en slegs hulle ekonomiese produktiwiteit was van belang. Die Helleniseringsproses is in die kusgebiede, die Joodse areas, met weerstand op godsdienstige gronde begroet. Die Grieke het slegs 'n verpligting gehad teenoor die familie en die staat; maar glad nie teenoor die armes nie. Armes het volgens Hengel (1973:48) in genoemde tyd 'n positiewe betekenis gehad: "Certain forms of the term 'poor' acquired virtuealy a positive religious significance, and in the sense of 'unjustly oppressed' the term came near to the word 'righteous', a development which would have been impossible with the Greeks, ....".

Op beide ekonomies-sosiale en godsdienstige gronde vind daar ontwikkeling plaas, waarin inherent groot konflik bestaan. 'n Relatiewe klein, ryk en magtige opperklas, gerugsteun deur hulle Griekse heersers, het gebots met die verteenwoordigers van die teokratiese getroues aan die Tora, wat bestaan het uit die laer priesterdom en die Leviete; en aan die ander kant, daardie groep waarin die profetiese tradisie voortgeleef het en waarin die apokaliptiek ontstaan het. Bogenoemde twee groepe het die indringing van die Grieke verafsku. Die opperklasse het gewoond geraak om kompromieë aan te gaan met die vreemdelinge en die Grieke. Skerp kontraste tussen die aristokrasie en die laer klasse is sodoende veroorsaak. Die kontraste is volgens Hengel (1973:50) bewaar in sekere laat Psalms, dele van Spreuke en latere dele van die profete. Die Joodse wysheidsliteratuur het nie die uitbuiting van die armes en strewe na rykdom veroordeel nie - maar die teendeel kry ons in die profetiese literatuur. In Spreuke is daar 'n veroordeling van armoede as iets wat iemand oor sigself bring, maar tegelykertyd is daar 'n veroordeling van ongeregtigheid en die arrogansie van die rykes, met simpatie vir die armes.

Die ekonomiese situasie van die gewone mense beskryf Hengel (1973:50) soos volg:

It is difficult to say how far the simple people shared in the fruits of the intensification of economic life under the first Ptolemies. Probably their lot, too, will have improved through the long period of peace. However, as the elaborate system of taxes and duties pressed hard on them and the social gulf between the thin upper stratum favourable towards the Greek customs and the mass of people became more striking, if not in fact greater, than in the Persian 
period, we must assume that the rule of the new foreigners found little approval in their sight.

Die aanloop tot die Makkabese opstand het bestaan uit 'n aanhangerstryd in Jerusalem. Die Hellenisties-kulturele invloed was hoofsaaklik gefokus op die hoofstad, Jerusalem. Ons het hier te doen met die ou stryd tussen die stad en die platteland. Die primêre ekonomiese invloed van die Hellenistiese samelewing en sy beperking tot die opperklas en die stad, het 'n rustige lewenstyl tot gevolg gehad. Die waarskuwings in Spreuke teen die luste en owerspel van die vreemde vrou en die verkeerde geniet van die lewe (rykdom) is op bogenoemde invloede gerig (vgl Hengel 1973:51, 52).

\section{SAMEVATTING}

Een van die grootste ontwikkelings op sosio-ekonomiese gebied van die antieke tyd is die ontdekking van die ysterploeg en die gebruik van dierekrag. Dit het die mens in staat gestel om 'n surplus te produseer, in plaas daarvan om net in die onmiddelike behoeftes te voorsien. Saam met die tegnologiese ontwikkeling het ook nuwe sosio-ekonomiese probleme gekom, naamlik groter klasverskille en differensiasie. Die elite het groter mag verkry en al meer van die surplus produksie vir hulleself opgeeis. Baie kleinboere het hulle plase verloor en slawe geword as gevolg van skuld. Die situasie kan saamgevat word met die stelling dat al meer grond in die hande van al minder gekom het. Die bewerking van die grond is baie hoog gewaardeer en as primêre arbeid beskou. Die groter ontwikkeling op sosio-ekonomiese en politieke gebied het die ontstaan van groter weermagte tot gevolg gehad. As gevolg van die groter sosiale diversifikasie moes die elite 'n sterk weermag hê om hulle mag en prestige te beskerm en om al meer belasting en produksie middele van die meerderheid kleinboere te verhaal. Hierdie algemene faktore was van die belangrike invloede op die sosio-ekonomiese en politieke ontwikkelings in die antieke tyd.

Die Hellenisme was baie duidelik 'n mag wat soos 'n vloedgolf die antieke tyd getref het. Elke lewensterrein is radikaal deur hierdie vloedgolf beïnvloed. Die Hellenisme het vooruitgang en stryd tot gevolg gehad. Groter ekonomiese ontwikkeling en geleenthede is geskep deur middel van die ineenskakeling van baie lande deur middel 
van taal en administratiewe sisteem van die Hellenisme. Die Hellenisme het vir die elite en aristokrasie meer geleenthede geskep, maar vir die meerderheid kleinboere het dit meer belastings en heffings tot gevolg gehad. Die hoër belastings het gelei tot groter differensiasie en verarming van die breë gemeenskap (laer strata). Grond het 'n bron van stryd geword tussen die elite en die kleinboere. Die eenheid van die magtige Romeinse Ryk van Aleksander die Grote het met sy dood tot 'n einde gekom. Die stryd om mag en posisie het onder sy generaals gewoed. Dit het gelei tot die verdeling van die Romeinse Ryk, sodat elke generaal 'n deel kon regeer (Diadochi-stryd).

Die Ptolemeërs het Palestina primêr oorheers vanuit strategiese en ekonomiese doeleindes. Die belangrikste handelsroetes is sodoende verseker en beskerm. Die regeerstelsel is so verfyn dat belastings makliker ingevorder kon word. Die verbeterde belastingstelsel het egter 'n verdere intensifisering van die stratifikasieproses tot gevolg gehad. Die rykes het ryker geword en die armes armer. Die koning het basies die alleen eienaar van die grond geword. Die koning het self besluit watter kleinboere op die gronde sou boer en wie van die amptenare grond as geskenk sal ontvang. Die koning kon weer die grond na willekeur terugneem. Die vreemde grondbeleid van die Ptolemeërs druis in teen die gebruik van grond in Israel. Vir Israel het God aan elkeen sy eie grond gegee, elke stam en familie. Die jubilee het bepaal dat die grond hulle onvervreembare erfreg is om daarop te woon en te werk.

Landbouproduksie het onder die regering van die Ptolemeërs toegeneem en sodoende ook die belastings op die goedere. Die politieke mag van die Ptolemeërs is dus gegrond op ekonomiese belange en vooruitgang. Die opperklasse of aristokrasie is bevoordeel omdat hulle met die belastinginvordering gehelp het. Die gewone bevolking is verder geëksploiteer. Die afstand tussen die elite en die gewone bevolking het al groter geword. Die ekonomiese eksploitasie het aanleiding gegee tot groter konflik en later politieke opstand.

Die gevolgtrekking kan dus gemaak word dat die basiese kernfaktore wat 'n rol gespeel het in die Bybelse jubilee, ook in die simplisties-agrariese samelewing sterk figureer, naamlik:

- Die stryd tussen grondbesit en grondloosheid.

- Groter sosiale stratifikasie as gevolg van eksploitasie deur die elite. 
- Die familiale instelling (veral die kleinboere) is onder geweldige druk.

- Toenemende konflik tussen die stad en platteland.

\section{Literatuurverwysings}

Crossan, J D 1998. The birth of Christianity: Discovering what happened in the years immediately after the execution of Jesus. New York: Harper Collins.

Edwards, R B 1992. s v Hellenism. Dictionary of Jesus and the Gospels, 312-317. Leicester: InterVarsity Press.

Fiensy, D A 1991. The social history of Palestine in the Herodian period. Lewiston, NY: Edwin Mellen. (Studies in the Bible and early Christianity 20.)

Finley, M I 1985. The ancient economy. New York: Penguin Books.

Goldin, J 1982. s v Josephus, Flavius. IDB.

Goodenough, E R 1928. The political philosophy of Hellenistic kingship. Yale Classical Studies 1, 55-102.

Gordon, C H 1982. s v Mesopotamia. IDB.

Hengel, M 1973. Judaïsm and Hellenism: Studies in their encounter in Palestine during the early Hellenistic period. Tübingen: Mohr.

Josephus, F 1926-1956. Works, tr by Thackeray, H J et al, 10 vols. London: Harvard University Press.

Kee, H C et al 1997. The Cambridge companion to the Bible. Cambridge: Cambridge University Press.

Lenski, G, Lenski, J \& Nolan P (1970) 1991. Human societies: An introduction to macrosociology. Sixth Edition. New York: McGraw-Hill.

Lenski, G E 1966. Power and privilege. New York: McGraw-Hill.

Louw, J P 1983. Hellenisme. Ongepubliseerde klasaantekeninge, Universiteit van Pretoria.

McLaren, J S 1998. Turbulent times? Josephus and scholarship on Judaea in the first century CE. Sheffield: Sheffield Academic Press. (Journal for the Study of the Pseudepigrapha - Supplement Series 29).

Oakman, D 1986. Jesus and the economic questions of his day. Lewiston: Edwin Mellon. (SBEC 8.) 
Pilch, J J 1997. Are there Jews and Christians in the Bible? HTS Theological Studies 51(1 \& 2), 119-125.

Stegemann, E W \& Stegemann, W 1999. The Jesus movement: A social history of its first century. Edinburgh: T \& T Clark.

Turner, N 1982. s v Aleksander. IDB.

Van Aarde, A G 1994. Kultuurhistoriese agtergrond van die Nuwe Testament: Die eerste-eeuse Mediterreense sosiale konteks. Pretoria: Kital.

Van Zyl, A H et al 1977. Israel en sy bure. Durban: Butterworths.

Volschenk, G J [2002]. Die ontwikkeling vanaf 'n simplistiese na 'n gevorderde agrariese ekonomie in die leefwêreld van die Bybel. Aanvaar vir publikasie in HTS Teologiese Studies 58(4).

Wilson, J A 1982. s v Egypt. IDB. 